\title{
Role of erythrocytes in the acute platelet response to operation
}

\author{
P. N. BENNETT
}

From the Department of Medicine, University of Aberdeen

SYNOPSIS A marked increase in platelet adhesiveness was shown to occur within four hours of operation. Postoperative red cells produced greater adhesiveness in platelets from a common pool than did preoperative red cells. A greater increase in platelet adhesiveness was observed following operation with the whole blood technique than when exogenous adenosine diphosphate was added to platelet-rich plasma. Release of adenosine diphosphate from red cells so facilitated may contribute to the acute platelet-adhesiveness response to operation.

Recent reports have drawn attention to the changes in platelet electrophoretic (Hampton and Mitchell, 1966) and adhesive (Ham and Slack, 1967) behaviour which follows closely upon surgical operation. Using the glass-bead column technique Bennett (1967) demonstrated a marked increase in the percentage of adhesive platelets on the first three postoperative days. This acute response of platelets to operation may be relevant to the inception of a thrombotic process which may take several days to produce clinical signs. Erythrocytes play an essential role in platelet adhesive behaviour as measured by systems in vitro (Hellem, 1960; Øllgaard, 1961; Caspary, 1965; Harrison and Mitchell, 1966) and probably also in vivo (Hellem, Borchgrevink, and Ames, 1961). It has also been suggested that after injury, characteristic changes in some properties of red cells take place (Gelin, 1956). Experiments were therefore undertaken to determine whether changes in red cells might underlie the altered behaviour of platelets after operation.

\section{MATERIALS AND METHODS}

Platelets were counted in blood diluted 1:20 with 1\% ammonium oxalate using phase-contrast microscopy.

Haematocrit was measured in a Hawksley microhaematocrit centrifuge.

Platelet adhesiveness was measured by the glass-bead column method of Hellem (1960) using $2.5 \mathrm{~g}$ columns of Ballotini no. 8 glass beads and a platelet-glass contact time of 21 seconds in whole blood anticoagulated with $1 / 10$ volume of $3 \cdot 13 \%$ sodium citrate, 15 minutes after venepuncture, which constituted standard conditions for the test, and in platelet-rich plasma (PRP) following the addition of adenosine diphosphate (ADP) (Sigma) in barbitone-buffered saline $p \mathrm{H} 7 \cdot 2$ to a final plasma concentration of $0 \cdot 1 \mu \mathrm{g} / \mathrm{ml}$.

The fall in the platelet count after passage of the blood or PRP through the columns was expressed as a percentage of the count before passage to give the percentage of adhesive platelets.

The subjects studied underwent major gastrointestinal tract (8), biliary tract (6), renal and renal tract (6), and breast (1) surgery. One subject in experiment II received 1 pint of blood at operation but no other subject received blood.

EXPERIMENT I Ten patients were studied. From $15 \mathrm{ml}$ venous blood withdrawn on the morning of operation and before premedication $5 \mathrm{ml}$ was used to test platelet adhesiveness under standard conditions (sample I). Ten $\mathrm{ml}$ was centrifuged at $300 \mathrm{~g}$ for $15 \mathrm{~min}$ at $4^{\circ} \mathrm{C}$, the PRP, buffy coat, and top $0.5 \mathrm{ml}$ of red cells were discarded, and the remaining red cell concentrate was stored at $4^{\circ} \mathrm{C}$. Six hours later, that is about four hours after operation, from a second blood sample totalling $25 \mathrm{ml}$ citrated blood $5 \mathrm{ml}$ was used to test platelet adhesiveness under standard conditions (sample II), two $10 \mathrm{ml}$ amounts were centrifuged as above and their PRP was pooled. The buffy coat and top $0.5 \mathrm{ml}$ of red cells were removed from one sample, thus forming a second red cell concentrate. Equal quantities of the fresh, pooled PRP were then mixed with each of the red cell concentrates (preoperative and postoperative) to reconstitute two samples of whole blood of equal haematocrit which was usually 40 to $50 \%$. Platelet adhesiveness was then tested in both samples. In seven of the 10 patients the entire process was repeated on the third postoperative day, drawing blood samples at the same times as on the day of operation, ie, first in the morning and secondly about six hours later.

EXPERIMENT II Eleven patients were studied on the day 
before and on the first and third days after operation. On each occasion platelet adhesiveness was tested in two ways on the same blood sample: (1) in whole blood under standard conditions, (2) by the ADP + PRP method (PRP was prepared by centrifugation at $190 \mathrm{~g}$ for 15 min at $4^{\circ} \mathrm{C}$ ); (3) in seven subjects blood from the same sample which had been centrifuged as for the preparation of PRP in (2) above was inverted to reconstitute whole blood and was tested for platelet adhesiveness simultaneously with (2) above.

\section{RESULTS}

EXPERIMENT I The percentage of adhesive platelets tested under standard conditions increased in all subjects four hours after operation (Table I) and the mean increase was $14.5 \%(\mathrm{P}<0.01)$. When platelet adhesiveness was tested using fresh pooled PRP, the samples which contained the postoperatives? red cells gave consistently higher levels than theo samples which contained the preoperative red cellsō and the mean difference between samples was $9.7 \%$ $(P<0.01)$. On the third postoperative day there $\Omega$ was no change in platelet adhesiveness over the timen of the experiment under standard conditions and, in fact, a slight mean fall of $1.8 \%(0.3>P>0.2)$ when adhesiveness was tested in fresh pooled PRP containing fresh red cells as compared to the samed PRP containing red cells which had been stored for six hours.

EXPERIMENT II Table II shows that, as measured byo the standard whole blood technique, the mean levelor

TABLE I

EFFECT OF PREOPERATIVE AND POSTOPERATIVE RED CELLS ON PLATELET ADHESIVENESS (MEANS WITH SEM)

\begin{tabular}{|c|c|c|c|}
\hline \multicolumn{2}{|c|}{$\begin{array}{l}\text { Standard Tests for } \\
\text { Adhesiveness }\end{array}$} & \multicolumn{2}{|l|}{$R B C$} \\
\hline $\begin{array}{l}\text { Sample 1 } \\
\text { (Pre- } \\
\text { operative) }\end{array}$ & $\begin{array}{l}\text { Sample } 2 \\
\text { (Post- } \\
\text { operative) }\end{array}$ & $\begin{array}{l}\text { Pre- } \\
\text { operative } \\
+ \\
P R P \\
\text { Post- } \\
\text { operative }\end{array}$ & $\begin{array}{l}\text { Post- } \\
\text { operative } \\
+ \\
P R P \\
\text { Post- } \\
\text { operative }\end{array}$ \\
\hline
\end{tabular}

\begin{tabular}{|c|c|c|c|c|c|c|c|c|c|}
\hline $\begin{array}{l}\text { Total platelet count } \\
(\times 1.000 / \mathrm{cmm})\end{array}$ & 209 & 226 & 184 & 194 & Total platelet count & 230 & 232 & 185 & 185 \\
\hline $\begin{array}{l}\text { SEM } \\
\text { percentage adhesive }\end{array}$ & 14 & 13 & 13 & 12 & SEM & 16 & 15 & 13 & 14 \\
\hline platelets & $41 \cdot 1$ & $55 \cdot 6$ & $34 \cdot 1$ & $43 \cdot 8$ & $\begin{array}{l}\text { platelets } \\
\text { pelative }\end{array}$ & $43 \cdot 2$ & $43 \cdot 2$ & $32 \cdot 4$ & $30 \cdot 6$ \\
\hline SEM & $3 \cdot 2$ & $\begin{array}{r}3 \cdot 0 \\
(n=\end{array}$ & $2 \cdot 5$ & $2 \cdot 2$ & SEM & $2 \cdot 2$ & $\begin{array}{r}1.9 \\
(n=\end{array}$ & $2 \cdot 7$ & $2 \cdot 3$ \\
\hline
\end{tabular}

TABLE II

SIMULTANEOUS MEASUREMENTS OF PLATELET ADHESIVENESS WITH THE WHOLE BLOOD AND THE 'ADP + PRP' METHODS IN PATIENTS BEFORE AND AFTER MAJOR OPERATIONS (MEANS WITH SEM)

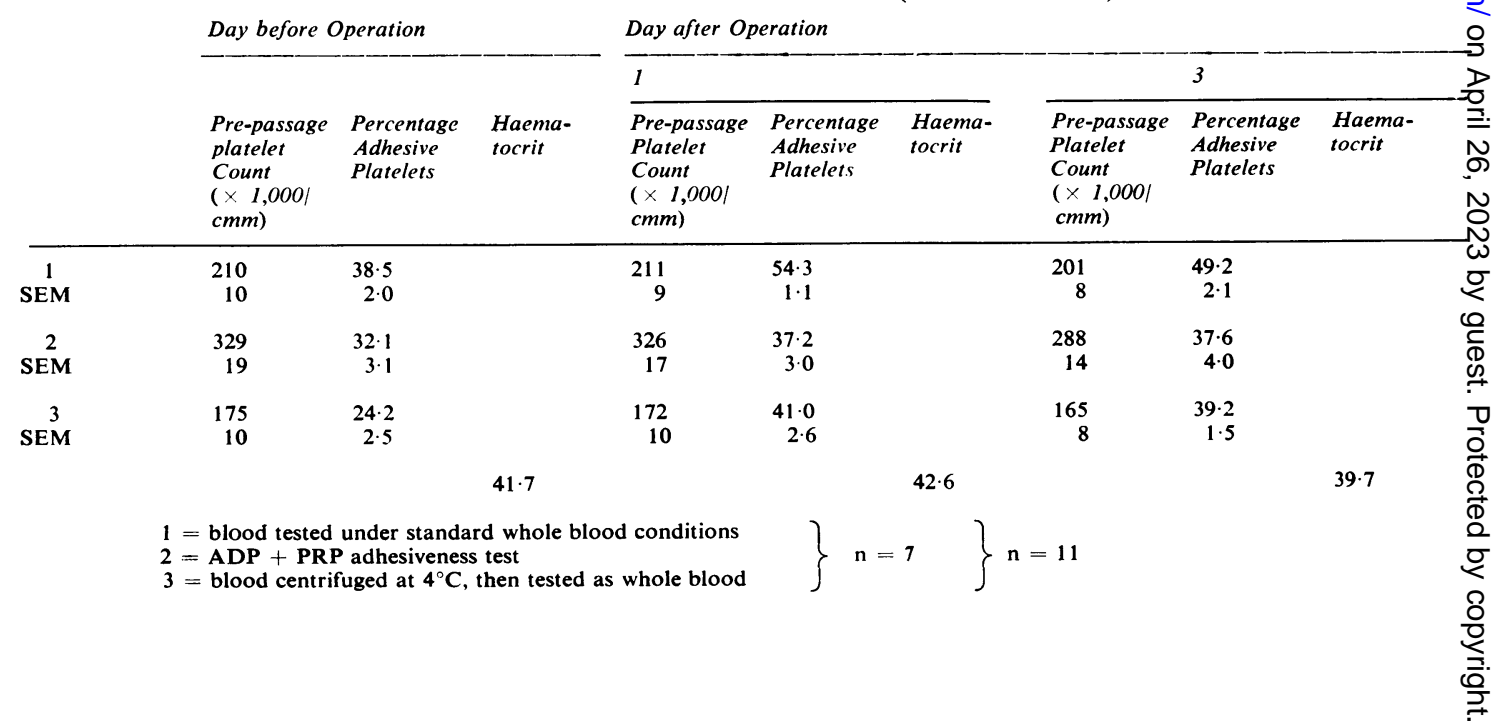


of platelet adhesiveness was on the first postoperative day $15.8 \%(\mathrm{P}<0.001)$ and on the third postoperative day $10.7 \%$ higher than the level before operation. In the same blood, platelet adhesiveness as measured by the 'ADP + PRP' method was also significantly raised but the magnitude of the change was much less, being on the first postoperative day $5.1 \%(0.05>P>0.02)$ and on the third postoperative day $5.5 \%$ greater than the mean preoperative level, Mean changes in haematocrit over the period of the experiment were small. Whole blood which had undergone manipulations similar to those required for the preparation of PRP showed changes in platelet adhesiveness which corresponded with blood tested in the standard manner, being on the first postoperative day $16.8 \%$ $(P<0.01)$ and on the third postoperative day $15.0 \%$ greater than the mean preoperative level.

\section{DISCUSSION}

Experiment I shows that increased platelet adhesiveness develops within four hours of operation. It is also clear that the differences observed between pre- and postoperative red cells must be attributed to operation and not to storage since no significant changes were found on the third postoperative day. The consistently higher platelet adhesiveness observed when red cells obtained four hours after operation were used indicates that surgery brought about a change in the erythrocytes which was reflected in platelet behaviour. Since platelet adhesion to glass depends on ADP released from red cells (Hellem, 1960; Gaarder, Jonson, Laland, Hellem, and Owren, 1961; Harrison and Mitchell, 1966) it would seem reasonable to ascribe this difference in platelet adhesiveness to facilitated release of ADP from postoperative red cells. This suggestion is supported by the fact that following operation the whole blood method demonstrated a larger increase in platelet adhesiveness than did the ADP + PRP method which requires a constant exogenous supply of ADP (experiment II). Simultaneously, however, it must be acknowledged that the observation of increased adhesiveness in PRP does indicate the activity of influences other than red cells at this time. It is unlikely that the process of preparation of PRP altered the postoperative platelet response since whole blood which had been similarly centrifuged and then reconstituted demontrated an equal response to whole blood tested in the standard manner. The lower absolute levels for platelet count and adhesiveness in this control sample were due to centrifugation (Bennett, personal observations).
An influence of red cells on haemostasis has long been known. Duke (1910) showed that the bleeding time in anaemic patients was shortened following red cell transfusion and Hellem et al (1961) demonstrated that platelet adhesiveness was increased by this procedure. Gelin (1956) has suggested that following trauma red cells are damaged by postcapillary stasis and Bergentz and Danon (1965) have shown that erythrocytes from injured rabbits become, within hours, mechanically more fragile. It is interesting to speculate that the trauma of surgery may alter red cells in such a manner as to facilitate their release of ADP.

Experimental studies show that for thrombus to form takes several days (Marin and Stefanini, 1960). The delay between operation and the time of maximal incidence of postoperative thrombosis (Nicolaysen, 1931; Pilcher, 1937; Barker, Nygaard, Walters, and Priestley, 1941) could therefore indicate that the acute platelet response to operation represents a critical phase in its inception. If this is so, modification of this phase by agents which suppress platelet adhesiveness might avert the sequence of events which leads to thrombosis. Support for this hypothesis is derived from the fact that the polyglucose dextran with a molecular weight of about 70,000 , which lowers platelet adhesiveness (Bygdeman, Eliason, and Gullbring, 1966), may also reduce postoperative thrombo-embolism when infused about the time of operation (Koekenberg, 1962). Clearly, therefore, changes in platelet activity which closely follow operation merit further study; the present work indicates that alterations in red cells underlie these changes at least in part.

The writer wishes to acknowledge the advice and criticism of Professor H. W. Fullerton in the preparation of this paper.

\section{REFERENCES}

Barker, N. W., Nygaard, K. K., Walters, W., and Priestley, J. T. (1941). Mayo Clin. Proc., 16, 17.

Bennett, P. N. (1967). J. clin. Path., 20, 708.

Bergentz, S. E., and Danon, D. (1965). Acta chir. scand., 130, 165. Bygdeman, S., Eliasson, R. and Gullbring, B. (1966). Thrombos. Diathes. haemorrh. (Stuttg.), 15, 451.

Caspary, E. A. (1965). Lancet, 2, 1273.

Duke, W. W. (1910). J. Amer. med. Ass., 55, 1185.

Gaarder, A., Jonsen, J , Laland, S., Hellem, A., and Owren, P. A. (1961). Nature (Lond.), 192, 531.

Gelin, L. E. (1956). Acta chir. scand., suppl. 210.

Ham, J. M., and Slack, W. W. (1967). Brit. J. Surg., 54, 385.

Hampton, J. R., and Mitchell, J. R. A. (1966). Brit. med. J., 1, 1078.

Harrison, M. J. G., and Mitchell, J. A. R. (1966). Lancet, 2, 1163.

Hellem, A. J. (1960). Scand. J. clin. Lab. Invest., 12, suppl. 51.

Borchgrevink, C. F., and Ames, S. B. (1961). Brit. J. Haemat., 7, 42.

Koekenberg, L. J. L. (1962). Bull Soc. int. Chir., 21, 501.

Marin, H. M., and Stefanini, M. (1960). Surg. Gynec. Obstet., 110, 263.

Nicolaysen, J. (1931). Acta chir. scand., 69, 21.

Øllgaard, E. (1961). Thrombos. Diathes. haemorrh. (Stuttg.), 6, 86.

Pilcher, R. (1937). Brit. J. Surg., 25, 42. 